\title{
Composition of Vernoniaamygdalina and its Potential Health Benefits
}

\author{
Philippa C Ojimelukwe ${ }^{1}$, Nuria Amaechi ${ }^{2}$
}

\begin{abstract}
${ }^{1}$ Department of Food Science and Technology, Michael Okpara University of Agriculture, Umudike, Nigeria, philippaco60@gmail.com ${ }^{2}$ Department of Food Science and Technology, Abia State University Uturu, Nigeria
\end{abstract}

\begin{abstract}
Vernoniaamygdalina is a perennial shrub. It is a vegetable, commonly used in foods and traditional medicine in tropical Africa. Traditional users report that this plant possesses observable health benefits. It contains many nutrients and phytochemicals such as iodine, alkaloids, anthraquinones, edotides, sesquiterpene lactones and steroid glycosides. These bioactive compounds are associated with the plant's health benefits. This review is a comprehensive update on the composition of $V$. amygdalina, linked to its food and medicinal uses. Traditional medicinal uses not yet supported by scientific evidence have been indicated. Clinical studies to substantiate the health-promoting effects of this plant product are lacking. More animal models experiments are required to prove the potency of this plant product. Grey areas where research is required to promote effective use of this plant product are indicated. Metadata for the health benefits of this plant product is based on inferences from compositional analysis and animal bioassays. There is a need to establish these claims in humans. Sources of information for this review were obtained from online search engines. The searches were restricted to information available as primary or secondary sources and effort was made to keep to only recent literature. Very important literature before that was not recent was also included. There is only very little information on the food uses of $V$. amygdalina which has been related to potential health benefits. There are a lot of claims on this plant-based on ethnomedicine and traditional uses. Vernoniaamydgalina is rich in nutrients and phytochemicals and this invariable account for its positive influence on health. Compounds associated with its anticancer effects, antioxidant properties, antimalarial properties, anti-inflammatory properties, antimicrobial properties and hypolipidaemic effects have been identified but most mechanisms of action have not been elucidated in humans.
\end{abstract}

Keywords- Antioxidant properties, bioactive compounds, chemical composition, health benefits, Vernoniaamygdalina.

\section{INTRODUCTION}

Vernoniaamygdalina is a perennial shrub with leaves that have a bitter taste popularly known as bitter leaf. Some species are bitterer than others (Kokwaro, 1993). Consumers usually wash the leaves with water (sometimes with water and salt) to reduce bitterness. The leaves may also be boiled before washing, (or boiled after washing) in a bid to make it more palatable. Washing of bitter leaf involves intermittent squeezing. The leaves may be exposed to sunlight for short periods to ensure that it does not get too small during size-reduction involved in the squeeze-washing process. Local Nigerian names for $V$. amgdalina are: "Ewuro" (Yoruba) "Onugbu" (Igbo) "Oriwo" (Bini language), "Ityuna" (Tiv language), "Chusardoki or fatefate" (Hausa language) and "Etidot" (Ibiobio) (Kokwaro, 2009).

Traditionally, $V$. Amgdalina's is believed to be effective in preventive health care and for the management of several disease conditions in humans (Burkill, 1985). Several research studies suggest that its effective use is largely dose-dependent (Ibrahim et al., 2011). It may demonstrate toxic effects in some cases such as when it is being used to promote fertility (Saalu et al., 2013) or as an antimalarial (Omoregie et al., 2011). Hydrodistillation extracts of this plant product are rich in essential fatty acids (like oleic acid and linoleic acid) (Amaechi et al., 2018); essential oils with insecticidal properties such as eucalyptus; linalool; $\alpha$-pinene; and some natural preservatives such as benzene are found in $V$. amydalina (Asawalam et al., 2006). Acetone and methanol extracts of $V$. amygdalina contain steroid glycosides, sesquiterpene lactones and edotides (Oluwaseun et al., 2017). The leaves have been most extensively investigated and used, while the stem and roots have received limited research attention. The stem and roots have been identified to have anti-bacterial properties against periodontal bacteria, explaining its use as a chewing stick in some traditional settings. The distribution 
of bioactive compounds in plant parts (leaves, stem and roots) has not been fully established.

\subsection{Vernoniaamygdalinaplant}

Vernoniaamgdalina belongs to the Asteraceae (Compositae) family. This plant family is made up of herbs, shrubs, or trees. It is the largest family of flowering plants. It has up to 1,620 genera and more than 23,600 species (Kokwaro, 1993).Vernonia is a genus of about 1,000 species of herbs and shrubs and $V$. amygdalina as the most important species (Kokwaro, 2009). In Nigeria, Zimbabwe and South Africa, it is usually domesticated(Toyang and Verporte, 2013). The shrub is about $13 \mathrm{~m}$ high. The full-blown mature leaf is elliptical, petiolate and has a diameter of about $6 \mathrm{~mm}$ (Toyang and Verporte, 2013). The leaves are dark green with a characteristic odour and a bitter taste. The tree is commonly propagated through cutting (Anonymous, 1999). Vernoniaamygdalina grows in many parts of Africa. It regenerates easily, producing a large mass of forage and is drought resistant (Bonsi et al., 1995a). Figure 1 shows the leaves of Vernoniaamygdalina.

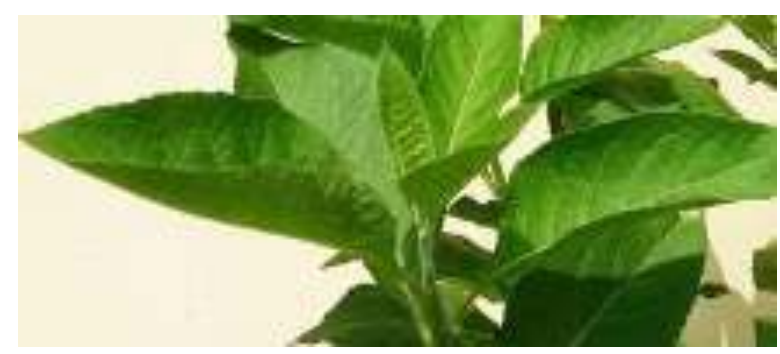

Fig.1. Vernoniaamygdalina leaves.

\section{NUTRIENT COMPOSITION AND HEALTH BENEFITS OF VERNONIAAMYGDALINA}

$V$ amygdalina is rich in nutrients. The protein content of the leaves is quite high (sometimes up to 20\%). The lipid content is also relatively high $(4.7 \%)$ when compared with other leaves. There is the need to carry out further research on the protein and lipid profile of $V$. amygdalina to have better understanding of the nutrient benefits of the plant product. The stem and the root contain significant amounts of fat (34.03 and 30.15\%) respectively (Bonsi et al., 1995b). The leaf contains higher amounts of the mineral elements iron and copper than the stem and the roots (see Table 1a). It contains significant amounts of ash $(8-17 \%)$. The leaf is particularly rich in iodine $(35.8 \mu \mathrm{g})$, iron $(5-14 \%)$ and copper $(6-10 \mathrm{mg} / 100 \mathrm{~g})$. It is also rich in thiamine, vitamin A and vitamin E (Table 1a). Other nutrients, found in $V$. amygdalina leaves that have been studied are presented in Table $1 \mathrm{~b}$. $V$. amygdalina leaves are also rich in reducing sugars $(14.3 \%)$ especially sucrose $(13.2 \%)$. It is a good source of arabinose, maltose, galactose, glucose and fructose. It also contains significant amounts of the flatulent sugar: raffinose(see Table 1b).

Table 1a: Nutrient composition of Vernoniaamygdalina

\begin{tabular}{llll}
\hline Parameter & Leaves & Stem & Roots \\
\hline Protein (\%) & $19.23-45.1$ & 6.71 & 7.30 \\
Moisture (\%) & $7.92-91.4$ & 18.50 & 12.0 \\
Total lipids \%) & 4.70 & & \\
Fat (\%) & 0.4 & 34.03 & 30.15 \\
Ash (\%) & $7.72-15.2$ & 17.99 & 11.01 \\
Total carbohydrate(g) & 68.35 & - & - \\
Crude fiber (\%) & $1.5-9.75$ & - & - \\
Dietary fibre & 25.47 & - & - \\
Reducing sugar (g) & 14.31 & - & - \\
Energy & 392.67 & - & - \\
Carbohydrate (CHO) (\%) & 10.0 & - & - \\
Non detergent fiber (NDF) & $23.7-50.2$ & - & - \\
Acid detergent fiber (ADF) & $13.9-39.5$ & - & - \\
Hemicellulose & $3.5-11.5$ & - & - \\
Dry matter (\%) & 20.08 & - &
\end{tabular}




$\begin{array}{llll}\text { Minerals } & & & \\ \text { Magnesium } & 88.1-261.93 & - & - \\ \text { Sodium }(\mathrm{mg} / 100 \mathrm{~g}) & 8.5-136.36 & - & - \\ \text { Calcium }(\mathrm{mg} / 100 \mathrm{~g}) & 67-278 & - & - \\ \text { Phosphorus }\left(\mu \mathrm{g} \cdot \mathrm{g}^{-1}\right) & 61.6-67 & - & - \\ \text { Potassium }(\mathrm{mg} / 100 \mathrm{~g}) & 21.1-60.9 & - & - \\ \text { Zinc }(\mathrm{mg} / 100 \mathrm{~g}) & 8.05-51.08 & 0.14 & 0.26 \\ \text { Manganese }(\mathrm{mg} / 100 \mathrm{~g}) & 5.56 & & \\ \text { Iron }(\mathrm{mg} / 100 \mathrm{~g}) & 5.0-14.2 & 0.12 & 0.09 \\ \text { Copper }(\mathrm{mg} / 100 \mathrm{~g}) & 6.01-10.2 & 0.021 & 0.022 \\ \text { Iodine }(\mu \mathrm{g} / 100 \mathrm{~g}) & 35.82 & - & - \\ \text { Vitamins } & & & \\ \text { Ascorbic acid }(\mathrm{mg} / 100 \mathrm{~g}) & 20.4-228.4 & 49.00 & 10.30 \\ \text { Thiamine }(\mathrm{mg} / 100 \mathrm{~g}) & 100-170 & 0.50 & 0.37 \\ \text { Riboflavin }(\mathrm{mg} / 100 \mathrm{~g}) & 3.10 & 0.13 & 0.15 \\ \text { Nicotinamide }(\mathrm{mg} / 100 \mathrm{~g}) & 0.41-1.65 & 0.03 & 0.15 \\ \text { Pyridoxine }(\mathrm{mg} / 100 \mathrm{~g}) & 2.6 & - & - \\ \text { Vitamin A }(\mathrm{IU} / 100 \mathrm{~g}) & 30.90-34.6 & 21.5 & 30.90 \\ \text { Carotenoids }(\mathrm{mg} / 100 \mathrm{~g}) & 30.0 & - & - \\ \text { Vitamin E (IU/100g) } & 37.3 & 106.20 & 35.83\end{array}$

(Bonsi et al., 1995a; Bonsi et al., 1995b; Areghore et al., 1997; Akinyele et al., 2014; Ilondu, 2010; Georgewill and Georgewill, 2010)

Table 1b:Carbohydrates and proteins found in Vernoniaamygdalina Leaves

\begin{tabular}{|c|c|c|c|}
\hline $\begin{array}{ll}\text { Sugar Content } \\
\mathrm{mg} / 100 \mathrm{~g})\end{array}$ & Value & $\begin{array}{ll}\text { Amino } & \text { acid } \\
(\mathrm{mg} / 100 \mathrm{~g}) & \end{array}$ & Value \\
\hline Glucose & 7.20 & Glycine & 4.63 \\
\hline Sucrose & 13.20 & Cysteine & 1.84 \\
\hline Fructose & 6.00 & $\begin{array}{l}\text { Casein } \\
\text { hydrolysate }\end{array}$ & 96.99 \\
\hline Lactose & 2.61 & - & - \\
\hline Galactose & 6.56 & - & - \\
\hline Arabinose & 9.25 & - & - \\
\hline Raffinose & 5.10 & - & - \\
\hline Maltose & 7.24 & - & - \\
\hline $\begin{array}{l}\text { Reducing sugar } \\
\text { (g) }\end{array}$ & 14.31 & - & - \\
\hline
\end{tabular}

(Georgewill and Georgewill, 2010)

\subsection{Highlights of Important Nutrients found in $V$.} amygdalinaand their potentials for promoting health

\subsubsection{Minerals}

$V$ amygdalina is rich in zinc $(8.05-51.08 \mathrm{mg} / 100 \mathrm{~g})$, copper $(6.01-10.2 \mathrm{mg} / 100 \mathrm{~g})$ and iodine $(35.82 \mu \mathrm{g} / \mathrm{g})$. The wide range of values for copper and zinc are reports from different authors. World health Organizations recommendation for zinc $(2.27$ and $2.89 \mathrm{mg} /$ daily, respectively for pregnant and lactating women) is much lower than the observed values for $V$. amygdalina. The normal range of copper in the serum is $80-155 \mu \mathrm{g} / \mathrm{dl}$ for women and $70-140 \mu \mathrm{g} / \mathrm{dlfor}$ men). The FDA recommends $1 \mathrm{mg}$ iodine per day, while some experts have recommended up to $14 \mathrm{mg} / \mathrm{day}$. These values are much lower than the observed values for this plant product, indicating that regular consumption of $V$. amygdalina will ensure adequate amounts of the mineral elements for normal body functions. Iodine is normally found in sea products and lack of iodine and its health consequences has compelled national fortification programmes for public health improvement. Lack of iodine may lead to metabolic diseases such as goiter, cretinism, and impaired intellectual 
ability. It is a global public health issue that affects fertility and pregnancy. Symptoms of copper deficiency include inability to concentrate, fatigue and a poor mood. Low amounts of copper are associated with low dopamine levels(Lei et al., 2019).Zinc plays an important role in wound repair, immune response and tissue regeneration. Zinc deficiency affects the skin, brain cells, skeletal system, reproductive system and the gastrointestinal tract(Shivi et al., 2017). Iodine is required for the formation of thyroid hormones and proper functioning of the thyroid gland.In the human body, iodine banks are found in the breast and ovaries, suggesting that these two organs may require substantial amounts of iodine for their proper development and functions (Ahat et al., 2010).

\subsubsection{Vitamins}

Data from Table 1a shows that $V$. amygdalina is a rich source of vitamin A, vitamin $\mathrm{E}$ and thiamine. The stem is exceptionally rich in vitamin $\mathrm{E}$. Vitamin $\mathrm{A}$ is required for cell differentiation and reproduction in addition to its role in vision. It also boosts the immune system. Vitamin $\mathrm{E}$ has very strong antioxidant properties and is beneficial to lipid tissues. Thiamine is intricately involved in energy and carbohydrate metabolism. The content of these vitamins in $V$. amygdalina is higher than in many other green leafy vegetables. The daily requirement of vitamin A for adult women is $700 \mathrm{mcg}$ per day. Vitamin $\mathrm{B}_{1}$ is important for energy production through the breakdown of carbohydrates; activation of the immune system; communication between the brain and nerve cells and communication between cells and tissues. Thus the high content of vitamin $\mathrm{B}_{1}$ in $V$ amygdalina implies that this plant product will promote the overall health and wellbeing of humans. Alcohol impairs the transport of vitamin $\mathrm{B}_{1}$ to tissues where it can be utilized. This can result in cognitive impairment (Jadeja and Deuka, 2014).

\subsubsection{Protein, carbohydrate and Lipid content}

The protein content of $V$. amygdalina is comparatively high for green leafy vegetables (19.23-45.10\% for leaves; $6.71 \%$ for the stem and $7.30 \%$ for the root)and should be further investigated for its detailed amino acid profile. The lipid content is also high $(4.7 \%)$ and requires further research input to decipher the detailed lipid profile. V. amygdalina carbohydrate is a rich source of sucrose, arabinaose, maltose, galactose glucose and fructose. This leafy vegetable also contains significant amounts of raffinose which is a flatulent sugar (Georgewill and Georgewill, 2010)

\section{PHYTOCHEMICAL COMPOSITION OF VERNONIAAMYGDALINA}

Phytochemical screening shows that $V$. amygdalina contains alkaloids, steroids, flavonoids, phenols, saponins, terpenes, cyanogenic glucoside, tannin, anthraquinone, phytate, oxalate, lignans(Areghore et al., 1997). The phytochemical constituents of $V$. amygdalinaare shown in Table 1c.The phytochemical constituents of the stem and roots have received limited research attention.

Table 1c:Phytochemical constituents of V. amygdalina

\begin{tabular}{llll}
\hline Parameter & V. amygdalina leaf & Stem & Roots \\
\hline Total phenolics (mg/100 g DW) & 156.40 & - & - \\
Total flavonoids (mg/100 g DW) & 6.25 & - & - \\
Saponin (\%) & $1.425-5.97$ & 13.21 & 0.51 \\
Flavonoid (\%) & 4.89 & 1.02 & - \\
Tannin & 9.62 & - & - \\
Phytate & 3.95 & - & - \\
Oxalate & $0.62-5.36$ & - & - \\
Cyanogenic glycoside & 1.11 & - & 6.11 \\
Alkaloids (\%) & 2.16 & 7.02 & - \\
Anthraquinone & 0.14 & - & - \\
Steroid & 0.38 & - & - \\
Phenol & 3.24 & - & - \\
Polyphenols (mg/100g) & 9.75 & - & \\
\hline
\end{tabular}

(Udochukwu et al., 2015) 
3.1. Phytochemical compounds fromVernoniaamygdalinawith scientifically established medicinal properties

Bioactive compounds identified in $V$. amygdalina are many.

\subsubsection{Terpenoids:}

The terpenoids include several sesquiterpene lactones such as: vernolide, vernodalol, vernolepin, vernodalin, vernomygdin, hydroxyvernolide, vernodalinol, vernomenin, vernolic, 11, 13-dihydrovernodalin, 11, 13dihydrovernorodeline, 4, 15-dihydrovernodalin, 1, 2, 3, 15, 11, 13, 2', 3'-octahydrovernodalin and epivemodalol(Njan et al., 2008). Some of these compounds may be associated with the ability of V. amygdalina to regulate blood sugar (Njan et al., 2008; Nwaoguikpe, 2010; Amaechi et al., 2018).

\subsubsection{Flavonoids}

The flavonoids found in this plant are luteolin (a flavone); luteolin 7- $0-\beta-$ glucoside, myricetin $\quad\left(3,5,7,3^{\prime}, 4^{\prime}, 5^{\prime}\right.$ hexahydroxyflavone) and luteoin 7-0- glucoronoside. The flavonoid content of the leaf is much higher than that of the stem and the roots. The nature of the flavonoids found in the stem and roots need to be studied in details. In higher plants, flavonoids are involved in the filtration of ultraviolet light, nitrogen fixation, cell cycle inhibition; as chemical messengers and for the protection of plants against certain diseases. Flavonoids are known to demonstrate two major mechanisms of action (either through direct scavenging of free radicals ;or interfering some enzyme activities such as with nitric oxide synthase activity or xanthine oxidase activity) (Nijveldt et al., 2001).

\subsubsection{Steroid glucosides:}

The steroid alcohol found in $V$. amygdalina is 7, 24 (28)stigmastadien-3- $\beta$-ol. The steroid glucosides isolated from $V$. amygdalina includevernoniosides $\mathrm{A}_{1}, \mathrm{~A}_{2}, \mathrm{~A}_{3}, \mathrm{~A}_{4} \mathrm{~B}_{1} \mathrm{~B}_{2}$ $\begin{array}{lllll}\mathrm{B}_{3} & \mathrm{D}_{1} & \mathrm{D}_{2} & \text { and vernoniosides } & \mathrm{E}\end{array}$ compounds have been isolated from $V$. amygdalina including Vernodalin, Vernomygdin, Vernoniosides $\left(\mathrm{A}_{1}\right.$, $\left.\mathrm{A}_{2}, \mathrm{~A}_{3}, \mathrm{~A}_{4}, \mathrm{~B}_{1}, \mathrm{~B}_{2}, \mathrm{~B}_{3}, \mathrm{D} \& \mathrm{E}\right)$, Vernodalol and Epivernodalol(Owen et al., 2011).

\section{MODE OF ACTION OF BIOLOGICALLY ACTIVE COMPOUNDS IN VERNONIAAMYGDALINA}

Some bioactive compounds from $V$. amygdalina have been associated with specific medicinal properties. The sesquiterpene lactones are associated with antimicrobial properties; antiprotozoal actions, and anti-tumour activities (Kupchan et al., 1969; Owoeye et al., 2010; Alara et al., 2017). The steroid glycosides possess antihelminthic and anti-inflammatory properties. They are also beneficial in handling gastrointestinal disorders. The edotides (peptides) have anticancer properties and relieve oxidative stress. The saponins lower cholesterol levels by interacting with bile acids causing accelerated metabolism of cholesterol in the liver, thereby making serum cholesterol levels to be reduced (Potter et al., 2008). Saponins may also suppress the production of mediators of inflammation such as histamine, serotonin and prostaglandin (Potter et al. 2008). They are also known to exhibit hypoglycaemic activity possibly by suppressing the transfer of glucose from the stomach to the small intestine and retarding glucose transport in the small intestine (Rao et al., 2004). The flavonoids and terpenoids all have anticancer, antioxidant, antimicrobial and hepatoprotective properties (Owoeye et al., 2010; Atangwho et al., 2012). Also, the terpenoids possess antileukemia, analgesic and anti-nociceptive properties (Khalafalla et al., 2009). Myricetin has been associated with hypolipidaemic and antidiabetic effects (Ref).Table 2 summarizes the specific actions of bioactive components of $V$. amygdalina. Mode of action of the bioactive compounds includes: causing a rise in the level of phase 11 enzymes; slowing down of the proliferation of cells; suppressing pro-inflammatory mediators.

Table 2:Phytochemical compounds in Vernoniaamygdalina leaves and their mode of action

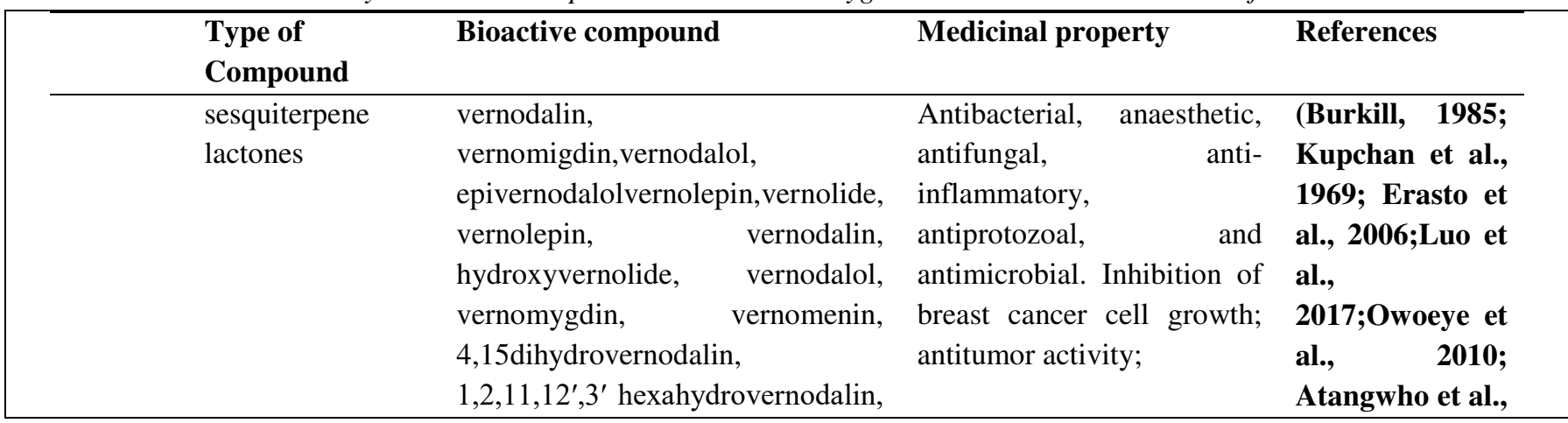




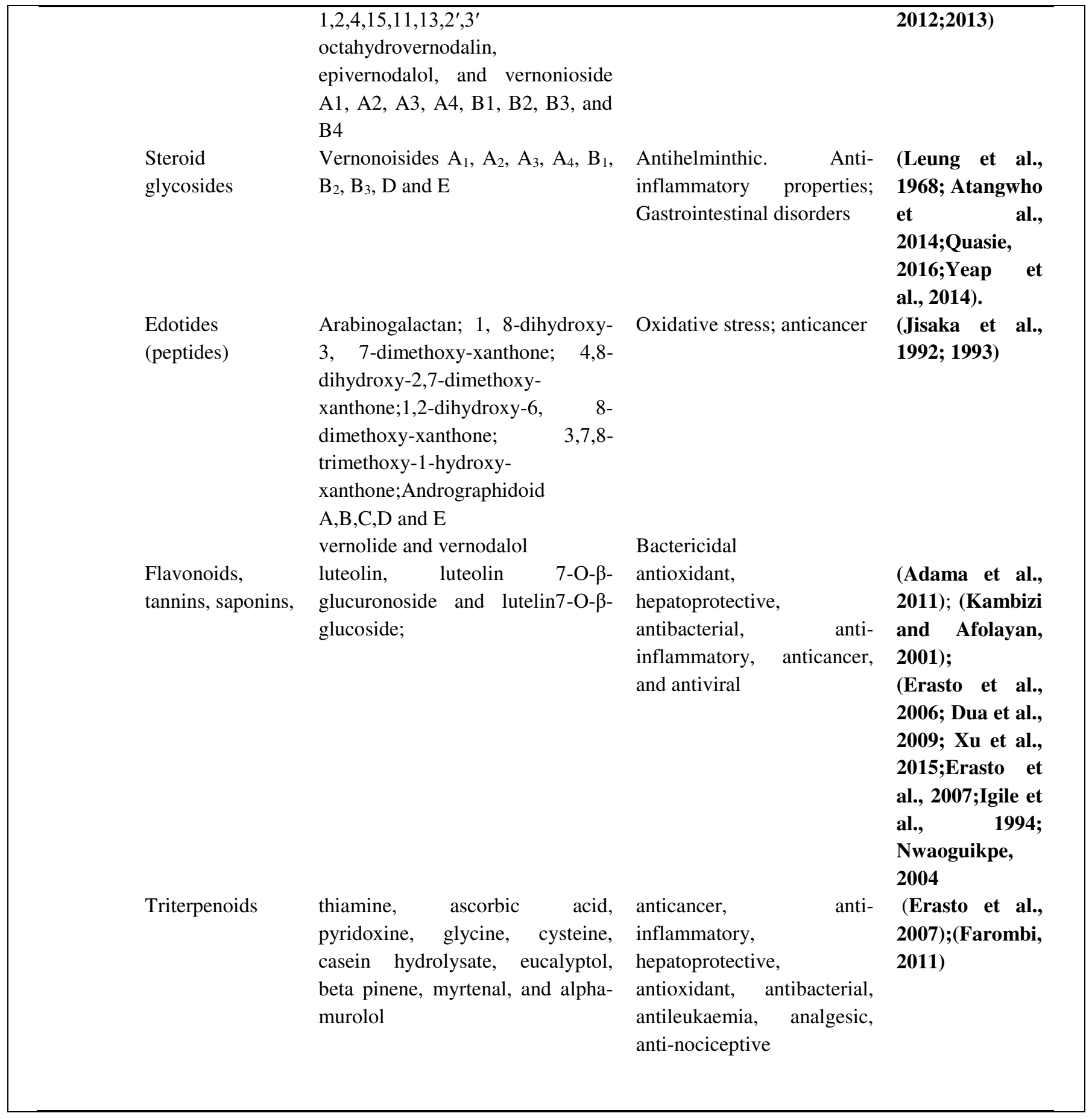

\section{Food uses of Vernoniaamygdalina}

The Vernoniaamygdalina leaves are mainly used for human consumption. Washing is often necessary to reduce the bitter taste caused by water-soluble saponins. The bitterness in $V$. amygdalina is caused by sesquiterpene lactones (e.g. vernodalin, vernolepin and vernomygdin) and steroid glucosides (vernoniosides). The fresh leaf is usually washed before it is added to food during preparation. V. amygdalina may be used to prepare dishes such as soups (Ogbono, Egusi, Okro and the popular bitter leaf soup), African breadfruit, yam porridge and the like The leaves are used as a vegetable and stimulate the digestive system. The leaves have been introduced in the beer brewing industry as an alternative to hops (Areghore, 1998). The stems are eaten by domestic animals. They are also used by humans as a chewing stick. The leaves may be used as a hop substitute and an antioxidant (Adama et al., 2011). The stem and roots of $V$. amygdalina are used as a medicinal chewing stick and in traditional health care. 


\section{ETHNOBOTANICAL USES OF V. AMYGDALINA}

Vernoniaamygdalina is widely used traditionally for the treatment and management of many ailments. In some settings, it is used to treat and manage diabetes, malaria and stomach disorder. They may be eaten to reduce fever. Furthermore, they are used as local medicine against leech, which feeds on blood and which may act as a potential reservoir for pathogenic viruses. The leaf extract may be applied to wounds, especially when fresh for quick healing. It is not usually applied to open stale wounds. Water extract of the leaves or the raw leaves may be chewed to reduce worm infestation, constipation, hiccups and kidney problems. A decoction of the leaves or the roots is also locally used for the treatment of schistosomiasis, cough, hepatitis, sexually transmitted diseases and microbial infections (Goergewill and Georgewill, 2010; Udochukwu et al., 2015). While the roots and the leaves of $V$. amygdalina are used in traditional medicine to treat fever, hiccups and kidney problems (Igile et al., 1995); the wood, from the root, may be used to clean the tooth (Okunlola et al., 2018). Fresh leaves of $V$. amygdalina have been reported to be very good as a purgative (Atangwho et al., 2017). It is used in some parts of Africa to prepare cough remedy (Egharevba et al., 2014).

\section{MEDICINAL USES OF VERNONIAAMYGDALINA}

Several research reports have shown that $V$. amygdalina possesses the following medicinal properties; it protects the liver; it is an antioxidant; it is an antimicrobial agent, and it prevents the agglutination of red blood cells. It is also chemoprotective, cytotoxic, anthelmintic, hypo-lipidaemic and abortifacient (Akinyele et al., 2014; Ilondu et al., 2010). Bitter leaf is also said to cure anorexia; Ascaris infestation, typhoid and breast cancer (Areghore et al., 1998).

\section{MANAGEMENT OF TYPE 2 DIABETES}

Vernoniaamygdalina has been observed to assist the regeneration of beta cells of the pancreas after they have been destroyed artificially by streptozotocin or alloxan (substances which are used to artificially induce diabetes in experimental animals. V. amygdalina promotes the uptake and utilization of glucose by muscle and liver cells of the human body. (Erasto et al., 2006; Luo et al., 2017; Amaechi et al., 2018). However, none of the isolated compounds (in this plant product) has been shown through research to be directly responsible for the anti-diabetic properties of $V$. amygdalina. Only limited studies have been carried out on the mechanism of anti-diabetic action of $\mathrm{V}$. amygdalina. The reports on mechanism of action in diabetes are scanty, since the derangements soon after the onset of the disease go beyond the $\beta$-cell sequestration, such that regeneration of $\beta$-cell alone may not entirely address the complications. It is necessary to study the impact of $V$. amygdalina on carbohydrate metabolism - the biological molecule whose metabolism is grossly affected in diabetic condition. Animal experiments showed a lot of accumulation of vacuoles in the pancreas of diabetic rats (Figure 3-negative control). The streptozotocin-induced diabetic pancreas showed apoptotic beta-cell alterations. The endoplasmic reticulum was more readily visible in the pancreas of diabetic rats. Ingestion of $V$. amygdalina reduced the accumulation of vacuoles; reduced the visibility of the endoplasmic reticulum and showed docked insulin granules (Amaechi et al., 2018).

7.2. Antimicrobial properties: Aqueous, ethanol and methanol extracts of $V$. amygdalina inhibit bacteria and fungi associated with the spoilage and pathogenicity of foods. Organisms such as Candida albicans, Pseudomonas aeruginosa, Bacillus subtilis, Staphylococcus aureus and Escherichia coli were found to be susceptible to extracts of $V$. amygdalina leaves. Chewing sticks made from Vernoniaamygdalina wood prevent the proliferation of periodontal bacteria. Leaves showed activities against various pathogenic bacteria and viruses. (Alo, 2012; Adetunji, 2013; Akinyele, 2014). Saponins, flavonoids, and alkaloids are responsible for the antimicrobial properties of V. amygdalina. Specific compounds which have been associated with the antimicrobial effects of this plant product include Dihydrovernodalin, vernodalol and vernolide (sesquiterpene lactones) (Akinyele, 2014).

\subsection{Cancer prevention and management}

Aqueous extracts of Vernoniaamygdalina leaves inhibit cell growth and multiplication. This biological activity enables it to retard the growth of cancer cells. In tests with rats, a sesquiterpene extract from the leaves of $V$. amygdalina was found to prevent liver damage. Vernoniaamygdalina extract is toxic to cancerous cells. It suppresses metastasis (the spreading of cancerous cells) (Izevbigie et al., 2014). It also suppresses the production of an enzyme which is responsible for the production of high levels of estrogen-a hormone associated with the development of breast cancer when it is produced in very high levels. The phytochemicals which are responsible for the anticancer effects of $\mathrm{V}$. amygdalina include: vernomygdin, vernodalin, vernomenin, and vernolepin (Izevbigie et al., 2014). 


\subsection{Antimalaria}

Extracts of leaves and root bark showed antimalarial activity against Plasmodium berghei which causes malaria when tested in vivo in mice and against Plasmodium falciparum in vitro (Kambizi and Afolayan, 2001). These extracts suppress the growth of malaria parasites. The leaf extract has also been observed to restore the efficiency of drugs like chloroquine after the malaria parasites had developed resistance towards them (Iwalokun, 2008; Njan et al., 2008; Egharevba et al., 2014).

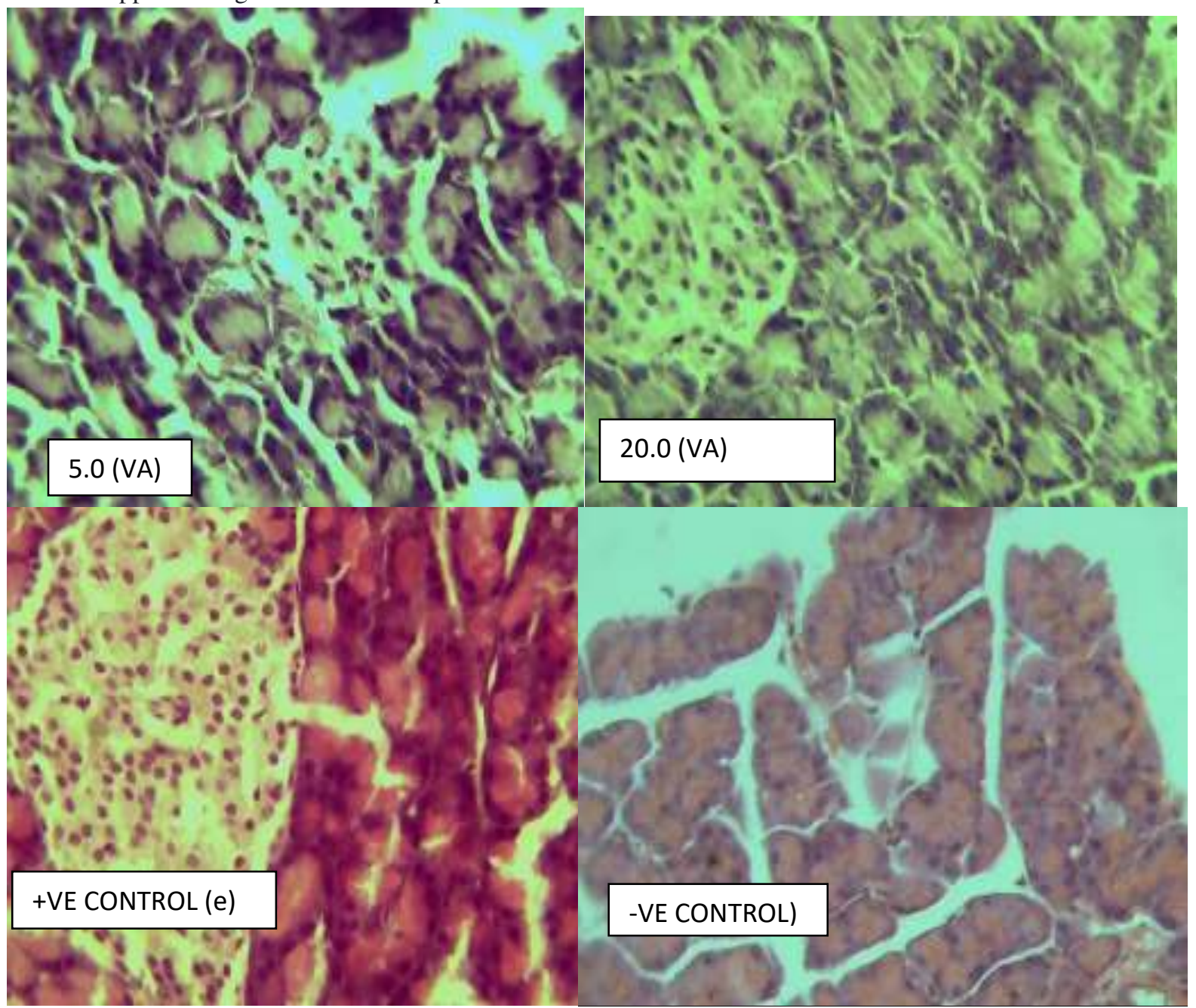

Source: [Amaechi et al., 2018]

Fig.3 Photomicrograph of sections of the pancreas from experimental rats fed Vernoniaamygdalinaat various concentrations.

Legend to Figure 3 Negative control refers to untreated diabetic animals,

Positive control refers to non-diabetic animals fed standard diet without plant product (Vernoniaamygdalina).

\subsection{Antioxidant properties}

Some chemical compounds isolated from the leaves of Vernoniaamygdalina (edotides, and sesquiterpene lactones) elicit remarkable antioxidant and chemopreventive properties in cell cultures and rodent models (Yeap et al., 2014; Wong et al., 2013; Abosi and Raseroka, 2003). The biochemical and molecular are mechanisms are fundamental to cancer prevention and boosting of the immune system. Inflammation may be caused by oxidative stress and will lead to the development of many chronic diseases. Antioxidants will ameliorate damages caused by radiation, pathogens or stress before more complicated disease situations develop(Hussain et al., 2016). 
Table 3: Potential health benefits of components of Vernoniaamygdaina

\begin{tabular}{|c|c|c|c|}
\hline $\begin{array}{l}\text { Potential health } \\
\text { benefit }\end{array}$ & $\begin{array}{l}\text { Nature of nutrients and } \\
\text { phytochemicals } \\
\text { involved }\end{array}$ & Possible mode of action & References \\
\hline Anti-malaria & $\begin{array}{l}\text { Vernodalin, } \\
\text { vernodalol,vernoleptin } \\
\text { vernolin, } \\
\text { hydroxyvernodalin }\end{array}$ & $\begin{array}{l}\text { It suppresses the growth of the } \\
\text { malaria parasite }\end{array}$ & $\begin{array}{l}\text { Kraft et al., 2003; Njanet al., 2003; } \\
\text { Tonaet al., 2004; Masaba, 2000; } \\
\text { Challad and Willcox, 2009; } \\
\text { Egharevba et al., } 2015\end{array}$ \\
\hline $\begin{array}{l}\text { Diabetes prevention } \\
\text { and management }\end{array}$ & Not yet known & $\begin{array}{l}\text { V. amygdalina enhances } \\
\text { glucose uptake and utilization } \\
\text { in muscle and liver cells; it } \\
\text { improves glucose tolerance } \\
\text { and postprandial blood } \\
\text { glcoselevels in normal } \\
\text { subjects. Regeneration of beta } \\
\text { cells of the pancreas. }\end{array}$ & $\begin{array}{l}\text { Erastoet al., 2009; Abraham, } \\
\text { 2007;Ebong et al., 2008; Etenget } \\
\text { al., 2008; Erasto et al., 2009; } \\
\text { Uchenna et al., 2008; Akpaso et } \\
\text { al., 2011; Ong et al., 2011; } \\
\text { Ojimelukweet al., 2012; Amaechi } \\
\text { et al., } 2018\end{array}$ \\
\hline Antioxidant activity & $\begin{array}{l}\text { Polyphenols, tannins, } \\
\text { saponins, flavonoids }\end{array}$ & $\begin{array}{l}\text { They ameliorate damages } \\
\text { caused by radiation, pathogens } \\
\text { And stress. }\end{array}$ & $\begin{array}{l}\text { Roginsky et al. 2003; Oboh et al., } \\
\text { 2008; Fasakin and Aluko, 2011; } \\
\text { Adesanonye et al., 2010; } \\
\text { Adesanoye and Farombi, 2010; } \\
\text { Farombi et al., 2011; Nwabjo, } \\
\text { 2005; Erasto et al., 2005; Haliwell } \\
\text { et al., 2005; }\end{array}$ \\
\hline $\begin{array}{l}\text { Antimicrobial } \\
\text { property }\end{array}$ & $\begin{array}{l}\text { Sesquiterpene lactones } \\
\text { (Vernodalol, } \\
\text { vernolide) }\end{array}$ & & $\begin{array}{l}\text { Udochukwu et al., 2015; Omoregie } \\
\text { et al., 2011; Adetunji et al., 2013; } \\
\text { Oyedeji et al., 2013; Alo et al., } \\
2012\end{array}$ \\
\hline $\begin{array}{l}\text { Cancer prevention } \\
\text { and management }\end{array}$ & Sesquiterpene lactones & $\begin{array}{l}\text { Vernodalinol inhibits the } \\
\text { growth of cancer cells }\end{array}$ & $\begin{array}{l}\text { Izevbigie et al., 2004; Sweeny et } \\
\text { al., 2005; Oputa and Izevbigie, } \\
\text { 2006; Gresham, 2008; Oyugi et al., } \\
\text { 2009; Yadjou et al., } 2013\end{array}$ \\
\hline $\begin{array}{l}\text { Hypolipidaemic } \\
\text { effect }\end{array}$ & & $\begin{array}{l}\text { Vernodalinol reduces the } \\
\text { cholesterol/lipid ratio }\end{array}$ & $\begin{array}{llll}\text { Adaramoye et al., } & 2007 \text {; } \\
\text { Adaramoye et al., } & 2008 \text {; } \\
\text { Adaramoye et al., } 2009 & \end{array}$ \\
\hline $\begin{array}{l}\text { Prevention } \\
\text { control } \\
\text { inflammation }\end{array}$ & $\begin{array}{l}\text { Tannins, flavonoids, } \\
\text { saponins, glycosides, } \\
\text { mineral elements }\end{array}$ & & Kim et al., 2004 \\
\hline
\end{tabular}

\section{CONCLUSION}

This review collates information on the nutrient and phytochemical composition of $V$. amygdalina and relates it to the health benefits associated with the plant. $V$. amygdalina is a protective food and should be consumed to promote health. Grey areas that need empirical research input are highlighted. Detailed chemical and nutrient composition especially of the stem and roots of $V$. amygdalina(phytochemicals, vitamins, minerals, and constituent sugars) should be determined in order to present a complete nutrient and chemical composition profile of this plant. In vitro and in vivo studies, cell culture assays; rodent model experiments and animal bioassays have been carried out to decipher the pharmacological effects of $V$. amygdalina, but more indepth research is needed as well as clinical studies with humans.

Areas that need more in-depth research include the mechanism of action of this plant product in cancer prevention, diabetes management and anti-inflammatory diseases management. Further research is also required to establish whether $V$. amydalina promotes fertility or not. There is need to understand whether the relationship between this plant product and fecundity is dependent on 
the plant part or on the dosage level or both. More animal experiments are required to ascertain traditional claims. More clinical trials are required to ascertain therapeutic effects. $V$. amygdalina is a potent food and medicinal plant that may be used in the dietary management of cancer and other tropical diseases. The full potential of this plant has not been fully exploited. This review stimulates further scientific research into the biological activities, with the view to discovering novel or lead pharmaceutical agents in Vernoniaamygdalina.

\section{DECLARATION OF INTEREST}

The author declares that there was no conflict of interest.

\section{REFERENCES}

[1]. Kokwaro, J .O. 1993. Medicinal plants of East Africa. 2nd ed. Kenya Literature Bureau, Nairobi, Kenya.

[2]. Kokwaro, J .O. 2009. Medicinal Plants of East Africa 3rd ed. Nairobi, Kenya: University of Nairobi Press.

[3]. Burkill, H.M. 1985. The Useful Plants of West Tropical Africa 2nd ed. Royal Botanical Gardens, Kew, London (1985).

[4]. Ibrahim, N.D., Abdurahman, E.M. and Ibrahim, G. 2001.Elemental analysis of the leaves of Vernoniaamygdalina and its biological evaluation in rats. Niger. J. Natl. Prod. Med. 5: 13-16.

[5]. Saalu, L.C., Akunna, G.G. and Oyewopo, A.O. 2013. The histomorfometric evidences of Vernoniaamygdalina leaf extract-induced testicular toxicity. Int J Morphol 31:662667.

[6]. Omoregie, S., Pal, A., and Sisodia, B. 2011. In vitro antimalarial and cytotoxic activities of leaf extracts of V. amygdalina (Del.). Nig J Basic Appl ScI. 19:121-12. http://www.ajol.info/index.php/njbas/index

[7].Amaechi, N.C., Ojimelukwe, P.C., and Onoja, S.O. 2018. Effects of Vernoniaamygdalina Leaf on nutritional and biochemical parameters in alloxan-induced diabetic rats $\mathbf{J}$ $\begin{array}{lllll}\text { Nutr Therapeutics } 7 & \text { (2018)) } & 1 \text { : 13-21. }\end{array}$ https://www.jbclinpharm.org/articles/antidiabetic-effect-ofcombined-aqueous-leaf-extract-of-vernonia-amygdalinaand-metformin-in-rats.html

[8]. Asawalam, E.F., and Hassanali, A. 2006. Constituents of the essential oil of Vernoniaamygdalina as maize weevil protectants. Trop SubtropAgroecosyst 6 (2006) 95-102. http://www.redalyc.org/articulo.oa?id=93960207

[9]. Oluwaseun, R.A., Abdurrahman, N., Siti, K. A. M., and Olusegun, A. O. 2017.Phytochemical and pharmacological properties of Vernoniaamygdalina: a review. J ChemEng Industrial Biotech. 2: 80-96. DOI: 10.15282/JCEIB-V207.29/9/2017/2.2

[10]. Toyang, N.J. and Verpoorte, R. A. 2013. Review of the medicinal potentials of plants of the Genus Vernonia (Asteraceae). J Ethnopharmacol. 146 (3): 681-723. https://doi.org/10.1016/j.jep.2013.01.040

[11]. Anonymous, (1999). http://bkbchina.com/fidelity/bitter.htm
[12]. Bonsi, M.K.L., Osuji, P.O., Tuah, A.K., and Umunna, N.N. 1995a. Vernoniaamygdalinaas a supplement to teff straw (Eragrostistef.) fed to Ethiopian Menz sheep. Agroforestry Systems.31(1995a) 3: $229-241$. https://link.springer.com/article/10.1007/BF00712076

[13]. Bonsi, M.K.L., Osuji, P.O., and Tuah, A. K. 1995b. Effect of supplementing teff straw with different levels of leucaena or sesbania leaves on the degradabilities of teff straw, sesbania, leucaena, tagasaste and vernonia and on certain rumen and blood metabolites in Ethiopia Menz sheep.Animal Feed Sci\& Tech. $52101 \quad-129$. https://doi.org/10.1016/0377-8401(94)00702-B

[14]. Aregheore, E.M.K., Makkar, H.P.S. and Becker, K. (1997) Chemical composition and tannins in leaves of some browse plants from Delta Central Nigeria eaten by ruminants. Proceedings of the Society of Nutrition Physiology, Frankfurt, Germany (1997) pp. 112.http://www.fao.org/livestock/agap/frg/Visit/Ida/Vernon ia\%20amygdalina.htm

[15]. Aregheore, E.M. K., Makkar, H.P.S. and Becker, K. 1998. Feed value of some browse plants from the central zone of Delta State. Nig Trop Sci. 38 (1998) 97-

104.www.fao.org/ag/AGA/AGAP/FRG/Visit/Ida/V ernonia\%20amygdalina.htm

[16]. Akinyele, B. J., Oladejo, B. O., Akinyemi, A. I. and Ezem, L. O. 2014. Comparative Study of the Antibacterial Effect of Mouth Washes and Vernoniaamygdalina (Del.) on Some Tooth Decay Causing Bacteria. British Microbiology Research Journal. 4(7): 749-758.

[17]. Ilondu, E.M. 2010. Phytochemical Composition and Efficacy of Ethanolic Leaf Extracts of Some Vernonia Species against Two Phytopathogenic Fungi. J Biopesticides. 6 (2): 165-172. https://pdfs.semanticscholar.org/18c8/a9f8e24d929 2097301f1b8889716798e3390.pdf

[18]. Georgewill, OA. andGeorgewill, U. O. 2010. Evaluation of the Anti-inflammatory Activity of Extract of Vernoniaamygdalina. Asian Pacific Journal of Tropical Medicine.150-151.DOI: 10.1016/S1995-7645(10)60057-0

[19]. Lei, S, Miriyala S., Keaton, MA, Jordan, CT, Wiedi C, Daret, K St Clair and Moscow, JA. (2014). Metabolic effects of acute thiamine depletion are reversed by rapamycin in breast leukemia cells. Plos One 9 (1): e85702. Aamir Ahmad. Editor

[20]. Shivi, M.D., Rubit, D.T., Gulotte, G., Wroblewski, K. and Pekov, J. 2017. Zinc deficiency is associated with poor clinical outcomes in patients with inflammatory bowel disease. Inflamm Bowel Diseases 23(1): 152-157

[21]. Ahat, F and Ganier, S. A. 2010. Iodine, Iodine metabolism and iodine deficiency disorders re-visited. Indian journal of Endocrinology and metabolism 14(1):13-17

[22]. Jadeja, R.N., Deuka, R.V. 2014. Chapter 47.Polyphenols and Flavonoids in Controlling Non-Alcoholic Steatohepatitis. In: Polyphenols in Human Health and Diseases 1:615-623. Academic 
Press.https://doi.org/10.1016/B9 78-0-12-398456-2.000475

[23]. Udochukwu,U. F.I., Omeje, I.S., Uloma, F.D., and Oseiwe, G. 2015. Phytochemical Analysis of Vernoniaamygdalina and Ocimumgratissimum Extracts and their Antibacterial Activity on Some Drug Resistant Bacteria.Amer J Res Commun. 3, 5: 225-235. http://www.usa-journals.com/wpcontent/uploads/2015/04/Udochukwu_Vol35.pdf

[24]. Njan, A. A. B., Adzu, A.G., Agaba, D., Byarugaba, S., Díaz-Llera, D.R. and Bangsberg U 2008. The analgesic and antiplasmodial activities and toxicology of Vernoniaamygdalina. J Med Food 11: 574-581. https://doi.org/10.1089/jmf.2007.0511

[25]. Nwaoguikpe, R. N. 2010. The Effect of Extract of Bitter Leaf (Vernoniaamygdalina) on Blood Glucose Levels of Diabetic Rats Int J Biol\&ChemSci 4: 721-729. https://10.4314/ijbcs.v4i3.60500

[26]. Owen, O.J., Amakiri, A.O., and Karibi-Botoye, T.A. 2010. Sugar-lowering effects of bitter leaf (Vernoniaamygdalina) in experimental broiler finisher chickens. (2010) Asian J Pharm \& Clinical Res 4 (1):19-21.

[27]. Kupchan, S. M., Hemingway, R.J., Karim, A, and Werner, D. 1969. Tumor inhibitors. XLVII. Vernodalin and vernomygdin, two new cytotoxic sesquiterpene lactones from Vernonia amygdalina Del. J Org Chem 34 (1969) 3908-3911. https://doi:10.1021/jo01264a035,

[28]. Owoeye, O., Yousuf, S., Akhtar, M.N., Qamar, K., Dar, A., Farombi, E.O., Onwuka, S.K., and Choudhary, M.I. 2010. Another Anticancer Elemanolide from VernoniaamygdalinaDel.(2010) Int. J BiolChemSci4:226234. http://ajol.info/index.php/ijbes

[29]. Alara, O.R., Nour, A., Adbul-mudalip, S.K., and Olalere, O. A. 2017. Phytochemical and pharmacological properties of Vernoniaamygdalina-A REVIEW. J ChemEng\& Industrial Biotechnol 2 (2017):80-96. https://doi: 10.15282/JCEIBV2-07.29/9/2017/2.2

[30]. Atangwho, I.J., Ebong, P.E., Eyong, E.U., Asmawi, M.Z. and Ahmad, M. 2012. Synergistic antidiabetic activity of Vernoniaamygdalina and Azadirachtaindica: Biochemical effects and possible mechanism. J Ethnopharmcol 141 (2012) 3:878-887. https://doi.org/10.1016/j.jep.2012.03.041

[31]. Atangwho, I.J., Yin, K.B., Umar, M.I., Ahmad, M., and Asmawi, M. Z. 2014. Vernoniaamygdalinasimultaneously suppresses gluconeogenesis and potentiates glucose oxidation via the Pentose Phosphate Pathway in streptozotocin-induced diabetic rats. BMCCompl\& Alt Med $\quad 14 \quad$ (2014) 1: 426. https://bmccomplementalternmed.biomedcentral.co m/articles/10.1186/1472-6882-14-426

[32]. Atangwho, I.J., Ebong, P.E., Eteng, E.U. and Eyong, A.U.(2017. Effect ofVernoniaamygdalina Del. Leaf on kidney function of diabetic rats. Int J Pharmacol 3 (2017) 2: 143-148. https://doi:10.3923/ijp.2007.143.148
[33]. Khalafalla, M., Abdellatef, E., Daffalla, H.M., Nassrallah, M., Aboul-Einen, M., Lightfoot, D.A., Cocchetto, A., and El-Shemy, H. 2009. Antileukemia activity from root cultures of Vernoniaamygdalina. J Med Plant Res 3 8:556562.

https://pdfs.semanticscholar.org/0f80/87074c5b360b884e0 84521b1a3b921880d94.pdf

[34].Erasto, P., Adebola, P.O., Grierson D.S and Afolayan A.J. (2005). An ethnobotanicalstudy of plants used for the treatment of diabetes in the Eastern Cape Province, South Africa. African Journal of Biotechnology, 4(12): 14581460.

[35]. Erasto, P., Grierson, D.S., and Afolayan, A. J. 2006. Bio active sesquiterpene lactones from the leaves of Vernonia amygdalina. J Ethnopharmacol 106:117-120. https://academicjournals.org/article/article1380714162_Ye ap\%2520et\%2520al.pdf

[36]. Erasto, P., Grierson, D. S, and Afolayan, A. J. 2007a.Antioxidant constituents in Vernoniaamygdalina leaves. Pharm Biol. 45:195-199.

[37]. Erasto P, Grierson DS, and Afolayan A .J. 2007b. Evaluation of Antioxidant activity and the fatty acid profile of the leaves of Vernoniaamygdalina growing in South Africa. Food Chem104: 636-642. https://doi.org/10.1016/j.foodchem.2006.12.013

[38]. Erasto, P., Venter, M., Roux, S., Grierson, D.S. and Afolayan, A. J. 2009.Effect of extracts of Vernoniaamygdalina on glucose utilization of chang-liver, C2C12 muscle and 3T3-L1 cells. Pharm. Biol. 47: 175-181.

[39]. Luo, X., Jiang, Y., Fronczek, F.R., Lin, C., Izevbigie, E.B., Lee, S. and Lee, K.S. 2017. Isolation and Structure Determination of a Sesquiterpene Lactone (Vernodalinol) from Vernoniaamygdalina Extracts. Pharm Biol 49 (5):464-470. https://doi: 10.3109/13880209.2010.523429

[40] Quasie, O., Zhang, Y., Zhang, H., Luo J, and Kong, L. 2016. Four New Steroid Saponins with highly Oxidized Side Chains from the Leaves of Vernoniaamygdalina. $\begin{array}{llll}\text { PhytochemLett } & 15: & 16- & \end{array}$ https://doi.org/10.1016/j.phytol.2015.11.002

[41]. Yeap, S.K., Ho, W.Y., Beh, B.K., Liang, W.S., KYH, Hadi A., and Alitheen, N.B. 2014. Vernoniaamygdalina, an ethnomedical used green vegetable with multiple bio-activities. J Med Plants
Res. 4(25):
2787-2812.

https://academicjournals.org/article/article1380714 162_Yeap\%2520et\%2520al.pdf

[42]. Jisaka, M., Ohigashi, H., Takagaki, T., Nozaki, H., Tada, T., Hirota, M., Irie, R., Huffman, M.A., Nishida, T., Kaji, M. and Koshimizu, K. 1992. Bitter steroids glucosides, vernoniosides $\mathrm{A} 1, \mathrm{~A} 2$, and $\mathrm{A} 3$ and related $\mathrm{B} 1$ from a possible medicinal plant, Vernoniaamygdalinaused by wild chimpanzees.Tetrahedron. 48: 625-632. https://doi.org/10.1016/S0040-4020(01)88123-0

[43]. Jisaka, M., Ohigashi, H., Takegawa, K., Hirota, M., Irie, R., Huffman, M.A., Koshimizu, K. 1993. Steroid glucosides from Vernoniaamygdalina, a possible chimpanzee 
plant.Phytochem

34:

409-413.

https://doi.org/10.1016/0031-9422(93)80019-O

[44]. Adama, J.K.K., Oberafo, A.A. andDika, S. 2011. Bitterleaf as Local Substitute for Hops in the Nigerian Brewing Industry. Scholars Research Library.3 (2011) 4: 388-397. http://connection.ebscohost.com/c/articles/73371518/bitterl eaf-as-local-substitute-hops-nigerian-brewing-industry

[45]. Kambizi, L. and Afolayan, A. J. (2001). An ethnobotanical study of plants used for the treatment of sexually transmitted diseases (njovhera) in Guruve District, Zimbabwe. J Ethnopharmacol 77: 59.https://doi.org/10.1016/S0378-8741(01)00251-3

[46]. Dua, V.K., Pandey, A.C., Raghavendra, K., Gupta, A., Sharma, T., and Dash, A.P. 2009. Larvicidal activity of neem oil (Azadirachtaindica) formulation against mosquitoes. Malaria J. 8 1:124.doi: 10.1186/1475-2875-8124

[47]. Xu, W., Zhou, Q., Yin, J., Yao, Y., and Zhang, J. 2015. Anti-diabetic effects of polysaccharides from Talinumtriangulare in streptozotocin (STZ) -induced type 2 diabetic male mice.Int J BiolMacromol [Internet]. Elsevier B.V. 72:575-9. Available from: https://dx.doi.org/10.1016/j.ijbiomac.2014.09.011

[48]. Farombi, E.O. and Owoeye, O. 2011. Antioxidative and chemopreventive properties of Vernoniaamygdalina and Garcinia biflavonoid.Int J Environ Res Public Health 8: 2533-2555.

[49]. Igile G O., Oleszek,W, and Jurzysta, M. D. 1995. Vernoniosides, two novel saponins from Vernonia amygdalina. J Nat Prod. 58:1438-1443. https://pubs.acs.org/doi/abs/10.1021/np50123a016

[50]. Okunlola, G.O., Jimoh, M., Olatunji, O.A., Ufai, A. and Omidiran, A. O. 2018. Proximate analysis, mineral composition, and antioxidant properties of bitter leaf and scent leaf.International J Veg Sci (2018) DOI: 10.1080/19315260.2018.1515141

[51]. Egharevba, C., Osaymwenre, E., Imieje, V., Ahomafor, J., Akunyili, C., Udu-Cosi, A. A. Onyekaba,T .J. Osakue, J. A., Iftikhar, A., and Falodun, A. (2014) Significance of Bitter Leaf (VernoniaAmagdalina) In Tropical Diseases and Beyond: A Review. Mal Chem Control \& Elimination.3 120. https://doi:10.4172/2090-2778.1000120

[52]. Egharevba, C., Osayemwenre, E., Imieje, V., Ahomafor, J.,Akunyuli, C., Adeyanju, A.,Udu-Cosi, Onyekaba, T., Osakue, J., Iftikhar, A., and Abiodun, F. 2015. Significance of Bitter Leaf (VernoniaAmagdalina) In Tropical Diseases and Beyond: A Review. Malaria Control \& Elimination

[53]. Alo, M. N., Anyim, C., Igwe, J.C., Elom, M. and Uchenna, D. S. 2012. Antibacterial Activity of Water, Ethanol and Methanol Extracts of Ocimumgratissimum, Vernoniaamygdalina and Aframomummelegueta. Pelagia Research Library. 3(2): 844-848.

[54]. Adetunji, C. O., Olaniyi, O. O. and Ogunkunle, A.T.J. 2013. Bacterial Activity of Crude Extracts of Vernoniaamygdalina on Clinical Isolates. Journal of Microbiology and Antimicrobials. 5(6): 60- 64.
[55]. Izevbigie, E.B., Bryant, J.L. and Walker, A. 2004. "Natural Inhibitor of Extracelular Signal-Regulated Kinases and Human Breast Cancer Cells". ExpBiol\& Medicine.229: 163-169

[56]. Nijveldt, R. J., van Hoorn, D.E.C., Boolens, P.G., van Norren, K., van Leeuwen, P.A.M., 2001. Flavonoids: a review of probable mechanisms of action and potential applications. The Amer J Clinical Nutr. 74 (4): 418-425

[57]. Kambizi L, Afolayan AJ (2001) An ethnobotanical study of plants used for the treatment of sexually transmitted iseases (njovhera) in Guruve District, Zimbabwe. J Ethnopharmacol 77: 5-9.

[58]. Iwalokun, B.A., Efedede,B.U., Alabi-Sofunde,J.A., Oduala,T., Magbagbeola, O. A. and Akinwande, A. I. 2006. Hepatoprotective and antioxidant activities of Vernoniaamygdalina on acetaminophen-induced hepatic damage in mice. J Med Food 2006; 9 (2006) 524-530. https://doi.org/10.1089/jmf.2006.9.524

[59]. Wong, F.C., Woo, C.C., Hsu, A., and Tan, B.K.H. 2013. The anti-cancer activities of Vernoniaamygdalina extract in human breast cancer cell lines are mediated through caspase-dependent and p53-independent pathways. PLoS ONE 8(10): e78021. doi:10.1371/journal.pone.007802

[60]. Abosi, A.O., and Raseroka, B.H. 2003. In vivo antimalarial activity of Vernoniaamygdalina. Br J Biomed Sci 60 (2003) 89-91. https://doi: 10.1080/09674845.2003.11783680

[61]. Hussain, T., Tan, B., Yin, Y., Blachier, F., Tossou, M.C. B., and Rahu, N. 2016. Oxidative stress and inflammation: what can polyphenols do for us.Oxidation Medicine and Cellular Longevity.doi: 10.1155/2016/7432797

[62]. Kraft, C., Jenett-Siems, X, K. Siems, K, Jakupovic,JMavi S, Bienzle U, E. and Eich E. 2003. In vitro antiplasmodial evaluation of medicinal plants from Zimbabwe. Phytother Res. 17: 123-128.https:// 10.1002/ptr.1066

[63]. Tona,L., Cimanga, R.K., Mesia, K., Musuamba, C.T., Bruyne, T.D.E., Apers, S., N. Hernans, N.,. Van Miert, L., Pieters, J. Totté, A.J., and Vlietinck, G. 2004. In vitro antiplasmodial activity of extracts and fractions from seven medicinal plants used in the Democratic Republic of Congo. J Ethnopharmacol. 93: 2732.https://doi.org/10.1016/j.jep.2004.02.022

[64]. Masaba, S.C. 2004. The antimalarial activity of Vernonia amygdalina Del (Compositae). Trans R Soc Trop Med Hyg. 94 (2004): 694-695.https:// 10.1016/S0035-9203(00)90236$\underline{0}$

[65]. Challand, S., and Willcox, M. 2009.A clinical trial of the traditional medicine Vernoniaamygdalina in the treatment of uncomplicated malaria. J Altern Complement Med 15: 1231-1237.

[66]. Abraham AO (2007) Effects of Vernoniaamygdalina and chlopropamide on blood glucose. Med. J.Islamic World Acad. Sci. 16: 115-119. (Antidiabetic)

[67]. Ebong, P.E., Atangwho, I.J., Eyong, E.U., and Egbung, G.E. 2008. The antidiabetic efficacy of combined extracts from two continental plants: Vernoniaamygdalina (A. Juss) 
and Vernoniaamygdalina (Del.) (African Bitter Leaf). Am. J. Biochem. Biotech. 4: 239-244. (Antidiabetic)

[68]. Akpaso, M. I., Atangwho, I. J., Akpantah, A., Fischer, V.A., Igiri, A. O. and Ebong, P. E. 2011. Effect of Combined Leaf Extracts of Vernoniaamygdalina (Bitter Leaf) and Gongronemalatifolium (Utazi) on the Pancreatic $\beta$-Cells of Streptozotocin-Induced Diabetic Rats. British Journal of Medicine \& Medical Research. 1(11):24-34

[69]. Ong, K.W., Hsu, A., Song, L., Huang, D., and Tan, B.K. 2011. Polyphenols-rich Vernoniaamygdalinashows antidiabetic effects in streptozotocin-induced diabetic rats. J Ethnopharmacol 133: 598-607.

[70]. Ojimelukwe, P.C., Amaechi, N.C. and Akachukwu, D. 2016. Proximate Composition and Antihyperglycaemic Effects of Selected Plant Products. International Journal of Chemical and Biomedical Science 2(4): 28-33

[71] Roginsky, V. 2003. Chain-breaking antioxidant activity of natural polyphenols as determined during the chain oxidation of methyl linoleate in Triton X-100 micelles. Arch BiochemBiophys 414: 261-270.

[72].Fasakin, F. and Aluko, C. C. 2011. Antioxidant properties of chlorophyll-enriched and chlorophyll-depleted polyphenolic fractions from leaves of Vernoniaamygdalina and Gongronemalatifolium. Food Res. Intern. 44: 24352441

[73]. Adesanoye, O.A., and Farombi, E.O. 2010. Hepatoprotective effects of Vernoniaamygdalina (Astereaceae) in rats treated with carbon tetrachloride. Exp. Toxicol. Pathol.2010; 62:197-206

[75]. Nwanjo, H.U. 2005. "Efficacy of aqueous leaf extract of Vernoniaamygdalina on plasma lipoprotein and oxidative status in diabetic rat models". Nigerian J Physiological Sciences.20 (1-2): 30-42.

[76]. Oyedeji KO, Bolarinwa AF, Akintola AM (2013) Effect of Methanol Extract of VernoniaAmygdalina on Haematological and Plasma Biochemical Parameters in Male Albino Rats. Journal of Dental and Medical Sciences 3, 64-67.

[77]. Sweeney, C.J., Mehrotra, S., Sadaria, M.R., Kumar, S., Shortle, N.H., Roman, Y., Sheridan, C., Campbell, R.A., Murray, D.J., Badve, S., and Nakshatri, H. 2005. "The sesquiterpene lactone parthenolide in combination with docetaxel reduces metastasis and improves survival in a xenograft model of breast cancer". Mole.Cancer Ther.4 (6): 1004. 5.

[78]. Opata, M.M., and Izevbigie, E.B. 2006. "Aqueous V. amygdalina Extracts Alter MCF-7 Cell Membrane Permeability and Efflux". Int. J. Environ. Res. Public Health.3 (2): 174-179.

[79]. Gresham, L.J., Ross J, and Izevbigie, E. B. 2008.Vernoniaamygdalina: anticancer activity, authentication, and adulteration detection. Int $\mathrm{J}$ Environ Res Public Health 5: 342-348.

[80]. Oyugi, D.A., Luo X, Lee, K.S., Hill, B. and Izevbigie, E.B. 2009. Activity markers of the anti-breast carcinoma cell growth fractions of Vernoniaamygdalina extracts. ExpBiol Med (Maywood) 234: 410-417.
[81]. Yedjou, C.G., Izevbigie, E.B., and Tchounwou, P.B.1. 2013. Vernoniaamygdalina-Induced Growth Arrest and Apoptosis of Breast Cancer (MCF-7) Cells. Pharmacol Pharm 4.

[82]. Adaramoye, A.O., Achem, J., Akintayo, O.O. and Fafunso, M.A. 2007. Hypolipidemic effect of Vernoniaamygdalina, a tropical vegetable in rats fed on high cholesterol diet. Journal of Clinical Lipidology 1:467467

[83]. Adaramoye, O.A., Akintayo, O., Achem, J. and Fafunso, M.A. 2008. Lipid lowering effects of methanolic extract of Vernoniaamygdalina leaves in rats fed on high cholesterol diet. Vascular Health Risk Management. 4:235-241.

[84]. Adaramoye, O.A., Akintayo, O., Achem, J and Fafunso, M.A. 2009. Lipid lowering effects of methanolic extract of Vernoniaamygdalina leaves in rats fed on high cholesterol diet. Atherosclerosis Supplement. 10:1119-1119.

[85]. Kim, HP, Son, K.H., Chang HW, and Kang, S.S. 2004.Antiinflammatory plant flavonoids and cellular action mechanisms. J PharmacolSci 96: 229-245. 